\title{
Analisis Perbandingan Kinerja Keuangan Bank BNI Syariah Dan Bank Syariah Mandiri \\ Di Masa Pandemi Covid-19
}

Yoga Adi Surya

Fakultas Ekonomi dan Bisnis Islam IAIN Tulungagung, Indonesia Email: adisuryayoga@gmail.com

Binti Nur Asiyah

Fakultas Ekonomi dan Bisnis Islam IAIN Tulungagung. Indonesia Email: binti.advan@gmail.com

\begin{abstract}
:
Financial performance as a measurement to determine the process of implementing financial resources owned by the company. Covid-19 pandemic has an impact on the banking sector, resulting in non-performing financing due to debtor arrears as a result of many people losing their jobs and difficulties in paying credit. This study has the objective of analyzing the comparative financial performance between Mandiri Shariah Bank and BNI Shariah Bank during the Covid-19 pandemic, using quarterly financial statements 1, 2, 3 and 4 for 2019 and quarter 1 for 2020 and through Independent testing T-Test sample. There are financial performance differences between BNI Shariah Bank and Mandiri Shariah Bank from ROA, NPF and BOPO aspects, whereas in terms of CAR and ROE aspects show significantly there are no differences performances between BNI Shariah Bank dan Mandiri Shariah Bank. This paper recommends that BNI Syariah pay attention to the ROE and NPF ratio, while to Bank Syariah Mandiri to pay attention to the CAR, ROA and BOPO ratios.
\end{abstract}

Kata Kunci: Financial Performance, Bank Syariah, Covid-19

\section{Abstrak}

Kinerja keuangan sebagai alat ukur untuk mengetahui proses melaksanakan sumberdaya keuangan yang dipunyai oleh perusahaan. Pandemi Covid-19 berdampak pada sektor perbankan sehingga mengakibatkan pembiayaan tidak lancar karena penunggakan debitur sebagai akibat dari banyaknya masyarakat kehilangan pekerjaan dan kesulitan untuk pembayaran pembiayaan. Penelitian ini mempunyai tujuan yakni melakukan analisis perbandingan kinerja keuangan antara Bank Syariah Mandiri dengan Bank BNI Syariah selama pandemi Covid-19, dengan menggunakan catatan laporan keuangan triwulan 1, 2, 3 dan 4 untuk tahun 2019, triwulan 1 untuk tahun 2020 dengan melalui pengujian Independen Sampel T-Test. Terdapat perbedaan antara kinerja keuangan Bank BNI Syariah dan Bank Syariah Mandiri dari aspek ROA, NPF dan BOPO, dan sedangkan dari segi aspek CAR dan ROE menunjukkan bahwa secara signifikan tidak ada perbedaan antara kinerja keuangan Bank Syariah Mandiri dan Bank BNI Syariah. Paper ini merekomendasikan kepada BNI Syariah agar memperhatikan rasio ROE dan NPF, sedangkan kepada Bank Syariah Mandiri agar memperhatikan rasio CAR, ROA dan BOPO.

Kata Kunci: Kinerja Keuangan, Bank Syariah, Covid-19 


\section{PENDAHULUAN}

Perbankan syariah menjadi salah satu lembaga keuangan yang mempunyai fungsi penyeimbang, penyelaras serta penyerasian berbagai sektor perekonomian. Peranan strategis dalam perekonoman tersebut yaitu untuk meningkatkan kualitas penghidupan warga negara secara keseluruhan melalui stabilitas nasional serta pertumbuhan ekonomi.

Bank yakni "Department of store, yaitu sebuah badan ataupun organisasi yang memberikan pelayanan/jasa untuk bermacam-macam jasa keuangan yangmana aktivitas vitalnya yakni melakukan penerimaan pembayaran, tabungan, simpanan giro serta deposito, yang digunakan untuk dapat melakukan pinjaman kredit/uang yang ditujukan pada setiap kebutuhan masyarakat, serta bank merupakan tempat yang digunakan dalam melakukan penukaran uang. ${ }^{1}$

Perbankan menurut Undang-undang No.7 tahun 1992 kemudian direvisi oleh Undangundang No.10 Tahun 1998 menyatakan bahwa bank merupakan suatu badan usaha dalam upaya untuk melakukan peningkatan tingkatan penghidupan masyarakat, melakukan penghimpunan dana dari masyarakat yang bentuknya suatu simpanan kemudian disalurkan lagi untuk masyarakat dengan bentuknya suatu kredit maupun yang lainnya. Bank syariah memiliki definisi bank yang menjalankan kegiatan usahanya berdasarkan prinsip syariah, yang jenisnya terdiri dari Bank Umum Syariah dan Bank Pembiayaan Rakyat Syariah. ${ }^{2}$ Fungsi lainnya yang dimiliki bank yakni sebagai Financial Intermediary, adalah sebuah lembaga yang berperan untuk dapat mempertemukan antara sang pengguna dan sang pemilik dana. Dengan begitu, aktivitas perbankan wajib terus berproses dengan efisien dan efektif berdasarkan skala makro dan mikro.

Pesan uraian di atas dapat disimpulkan jika bank berfungsi sebagai financial intermediary dan untuk melakukan peningkatan penghidupan masyarakat, melakukan penghimpunan dana dari masyarakat yang bentuknya suatu simpanan kemudian disalurkan lagi untuk masyarakat dengan bentuknya suatu pembiayaan maupun yang lainnya. Fungsi dari bank yaitu: 1), yaitu Sebagai Agent of Trust memiliki arti pedoman penting dari aktivitas sebuah bank yakni kepercayaan (trust) dalam melakukan penyaluran dan penghimpunan dana. Pentingnya kepercayaan dari masyarakat yang ingin menyimpan dananya pada bank dan percaya jika uang yang dimilikinya tidak akan disalahgunakan dari pihak bank. Bank perlu mengelola dengan baik uang yang dititipkan oleh nasabah, sehingga bank tidak merugi, dan dengan mudah simpanan nasabah dapat diambil dikemudian hari. Dengan cara ini masyarakat memiliki kemauan menyimpan dana pada bank. Masyarakat yakin jika pihak bank tidak akan menyalahgunakan dana mereka.

Jika tersebut adalah bank syariah dipercaya, maka sebaliknya, nasabah yang amanah menjadi landasan unsur kepercayaan dari pihak bank terhadap nasabah. Bank dengan seksama percaya menempatkan dana yang dikelola pada usaha nasabah, maupun kebutuhan nasabah lainnya. Kepercayaan yang dimiliki oleh pihak bank yakni bahwa pinjaman oleh pihak peminjam (debitur) ini tidak disalahgunakan. Dana pinjaman/pembiayaan digunakan dengan sebaik-baiknya oleh nasabah, dana dikembalikan pada waktu sudah jatuh tempo. Hal

\footnotetext{
${ }^{1}$ Sutiman, "Analisis Rasio ROE dan ROA Dalam Menilai Tingkat Kesehatan Pada PT Bank Mandiri (Persero) Tbk Tahun 2012-2017”, Jurnal Mandiri: Ilmu Pengetabuan, Seni, dan Teknologi, Vol. 3, No. 1 (Juni 2019):20-36.

2 Pasal 1, Undang-Undang Nomor 21 Tahun 2008 tentang Perbankan Syariah
}

Iqtishadia: Jurnal Ekonomi dan Perbankan Syariah

Vol.7 No.2 Desember 2020 
terpenting terkait pembiayaan ini yaitu pihak nasabah mempunyai niat guna bisa melakukan pengembalian dananya sekaligus berbagai kewajiban yang lain, dimana memiliki keterkaitan pada pinjaman/pembiayaan. 2), yaitu sebagai Agent of Development yang berarti bahwa wajib adanya sebuah keterkaitan diantara sektor riil dengan sektor keuangan dalam aktivitas ekonomi masyarakat. Interaksi keduanya harus terus memberikan pengaruh satu sama lain, yakni diantara sektor keuangan dengan sektor riil, keduanya saling berkaitan. Begitu perlunya sebuah aktivitas bank yakni dalam menghimpun juga menyalurkan dana untuk kelancaran aktivitas ekonomi pada sektor riil. Terdapat sebuah kemungkinan yang berasal dari kegiatan bank ini, bahwa nasabah bisa menjalankan kegiatan ekonomi yang meliputi aktivitas konsumsi barang/jasa, investasi, maupun distribusi, ketiga aktivitas ekonomi tersebut tidak terlepas dari penggunaan uang serta lancarnya sebuah aktivitas ini, yang tujuannya adalah sebagai aktivitas untuk menunjang pembangunan ekonomi suatu negara. 3), yaitu sebagai Agent of Service memiliki arti hal lainnya yang bisa dilakukan oleh bank yang mana kegiatan utamanya adalah penghimpunan dan penyaluran dana yakni bisa memberikan berbagai penawaran jasa dari bank yang lainnya untuk masyarakat. Adanya keterkaitan yang diantara jasa yang ditawarkan oleh masyarakat ini dan aktivitas ekonomi masyarakat pada umumnya. Hal-hal lain yang ditawarkan ini meliputi transfer uang atau jasa pengiriman uang, pemberian jaminan bank, penyelesaian tagihan, serta bisa dalam menitipkan barang berharga. ${ }^{3}$

Apabila ditinjau berdasarkan aspek penggunaan dana dengan imbalan jasa pada perbankan, meliputi pinjaman ataupun simpanan, bank bisa dikategorikan sebagai berikut: 1), Bank Konvensional yakni bank yang mana pada aktivitas operasionalnya meliputi menyalurkan maupun menghimpun dana, melakukan pemberian dan memberikan imbalan yaitu bunga ataupun sebesar imbalan pada suatu persentase berdasarkan dana pada sebuah jangka waktu. Persentase tersebut penetapannya per tahun secara umum. 2), Bank syariah yaitu bank yakni bank yang mana pada aktivitas operasionalnya yaitu meliputi menyalurkan ataupun menghimpun dana melakukan pemberian dan memberikan imbalan berdasarkan prinsip syariah yakni bagi hasil serta jual beli.

Bank syariah adalah "bank dimana melaksanakan aktivitas operasionalnya yaitu berpedoman pada prinsip agama Islam/syariah". ${ }^{4}$ Islam melarang adanya sistem riba karena hal tersebut memberatkan oleh salah satu pihak, sesuai dengan hal tersebut maka kegiatan operasional perbankan syariah berdasarkan kemitraan atau bagi hasil pada segala aktivitas bisnis atas dasar keadilan dan kesesuaian. Bank syariah adalah lembaga keuangan yang usaha pokoknya memberikan kredit dan jasa-jasa lain dalam lalu lintas pembayaran serta peredaran uang yang beroperasi dengan prinsip-prinsip syariat Islam. ${ }^{5}$

Berdasarkan Surat Keputusan Direksi Bank Indonesia No. 32/34/KEP/DIR 12 Mei 1999 mengenai bank dengan prinsip syariah, pada dasarnya aktivitas dari bank syariah

\footnotetext{
${ }^{3}$ Linda Tamim. "Peran Perbankan Syarian Terhadap Pertumbuhan Sektor Riil Di Indonesia". Jurnal Akuntansi, Vol. 8, No. 1 (2016): 11-27.

${ }^{4}$ Totok Budisantoso dan Nuritomo, Bank dan Lembaga Kenangan Lain. (Jakarta: Salemba Empat, 2014,), 6.

${ }^{5}$ Heri Sudarsono, Bank dan Lembaga Kenangan Syariab: Deskripsi dan Ilustrasi. (Yogyakarta: Eksoria, 2012), 94.
}

172

Iqtishadia: Jurnal Ekonomi dan Perbankan Syariah Vol.7 No.2 Desember 2020 
meliputi Mudarabah, Istishna, Kafalah, Ijarah Wa Iqtina, Ijarah, Hiwalah, Qardh, Musyarakah, Ujr, Salam, Al Rahn, Al Qard Ul Hasan, Sharf, Wakalah, Serta Wadi'ah.

Dalam beberapa tahun terakhir, pertumbuhan Perbankan syariah telah mengalami perkembangan signifikan. Untuk lebih jelasnya, pada tabel dibawah ini paparan mengenai perkembangan kelembagaan perbankan syariah di Indonesia yaitu:

Tabel 1

Perkembangan Kelembagaan Dan Kinerja Perbankan Syariah Indonesia

\begin{tabular}{lllllllllll}
\hline Indikator & 2010 & 2011 & 2012 & 2013 & 2014 & 2015 & 2016 & 2017 & 2018 & 2019 \\
\hline BUS & 11 & 11 & 11 & 11 & 12 & 12 & 12 & 12 & 14 & 14 \\
UUS & 23 & 24 & 24 & 23 & 22 & 22 & 22 & 22 & 20 & 20 \\
BPRS & 150 & 155 & 158 & 163 & 163 & 164 & 166 & 167 & 167 & 164 \\
Jaringan & 1,76 & 2,101 & 2,990 & 2,990 & 2,910 & 2,301 & 2,201 & 2,16 & 2,72 & 2,76 \\
Kantor & 3 & & & & & & & 9 & 4 & 4 \\
Aset (Milliar & 97,5 & 145,5 & 242,2 & 242,2 & 272,3 & 296,2 & 356,5 & 405, & 489, & 499, \\
Rp) & 19 & 67 & 76 & 76 & 43 & 6 & 0 & 30 & 69 & 34 \\
DPK (Milliar & 76,0 & 115,4 & 183,5 & 183,5 & 217,8 & 231,1 & 279,3 & 325, & 379, & 394 \\
Rp) & 36 & 15 & 34 & 34 & 58 & 7 & 3 & 06 & 96 & 72 \\
PYD (Milliar & 68,1 & 102,6 & 184,1 & 184,1 & 199,3 & 213,9 & 249,0 & 279, & 329, & 342, \\
Rp) & 81 & 55 & 22 & 22 & 30 & 9 & 9 & 13 & 28 & 81 \\
\hline
\end{tabular}

Sumber: Data Statistik Perbankan Syariah OJK

Perkembangan Industri perbankan Syariah pada tabel di atas memperlihatkan bahwa semakin menunjukkan keunggulan dalam memperkuat stabilitas system keuangan Nasional. Lembaga keuangan dalam hal ini perbankan yang memiliki peranan yakni untuk melaksanakan pencapaian tujuan pembangunan nasional, dengan begitu akibatnya adalah diperlukan suatu yang harus diawasi dan dibina secara efektif, sehingga lembaga perbankan di Indonesia sanggup atau dapat memiliki fungsi dengan sehat, wajar, efisien serta bisa melakukan penyaluran dana kepada masyarakat untuk bermacam-macam sektor yang produktif untuk mencapai tujuan pembangunan nasional.

Perbankan Indonesia diatur didalam Undang-undang RI No 10 Tahun 1998 pasal 1 Angka 1 yang menjelaskan jika perbankan adalah semua hal dimana memiliki keterkaitan dengan bank dan kelembagaannya, kegiatan usahanya serta petunjuk ataupun cara mengenai bagaimana jalannya suatu aktivitas usaha dari bank. Sedangkan, menurut Undang-undang RI No. 10 Tahun 1998 Pasal 1 Angka 2, bank merupakan suatu badan usaha dalam upaya untuk melakukan peningkatan tingkatan penghidupan masyarakat, melakukan penghimpunan dana dari masyarakat yang bentuknya suatu simpanan kemudian disalurkan lagi untuk masyarakat dengan bentuknya suatu kredit maupun yang lainnya.

Terdapat 2 (dua) jenis bank yang ada di Indonesia; Pertama, bank secara konvensional melakukan pembayaran bunga. Kedua, bank secara syariah melakukan operasionalnya didasarkan pada bagi hasil usaha. Munculnya bank syariah di antara perbankan konvensional memberi dampak positif bagi masyarakat. Perbankan konvensional melakukan prinsip riba atau bunga sehingga dengan adanya perbankan syariah maka masyarakat beralih bank

Iqtishadia: Jurnal Ekonomi dan Perbankan Syariah

Vol.7 No.2 Desember 2020 
berprinsip syariah. Bank syariah memiliki tujuan mengenalkan prinsip Islam pada berbagai transaksi keuangan serta industri perbankan dan bisnis terkait. ${ }^{6}$

Kinerja keuangan merupakan alat ukur untuk mengetahui proses pelaksanaan sumberdaya keuangan perusahaan. Hal itu melihat seberapa besar manjemen perusahaan berhasil, dan memberikan manfaat kepada masyarakat. Perbankan syariah terkandung di dalam Undang-undang Republik Indonesia No.21 tahun 2008 pasal 5, dimana Otoritas Jasa Keuangan ditugaskan melakukan pengawasan serta pembinanan untuk perbankan. Selanjutnya, undang-udang ini mempunyai ketetapan jika bank syariah diwajibkan melakukan pemiliharaan tingkatan kesehatan bank, yang mencakup kualitas manajemen Islam, solvabilitas, liquiditas, rentabilitas, serta kecukupan modal juga hal lainnya yang memiliki keterkaitan pada usaha perbankan syariah.

Saat ini, dunia sedang dalam masa melawan pandemi Corona Virus Desease (Covid-19) yang merupakan penyakit menular. Akibat dari virus tersebut, menyebabkan penyakit saluran pernafasan seperti flu, batuk, sakit tenggorokan, demam dan kasus yang lebih serius yakni pneumonia. Covid-19 ditemukan di Kota Wuhan China pada tahun 2019. Pada 2 Maret 2020, Presiden Jokowi mengumamkan kasus positif Covid-19 di Indonesia. Hingga saat ini, kasus positif Covid-19 di Indonesia berjumlah 45.029 kasus, 17.833 sembuh, dan 2.429 meninggal. ${ }^{7}$

Covid-19 bisa ditularkan dengan sangat cepat dari manusia ke manusia, sehingga jumlah positif kasus Covid-19 setiap harinya bertambah banyak. Usaha yang dilakukan pemerintah Indonesia guna melakukan pemutusan penyebaran Covid-19, dengan menerapkan kebijakan stay at home dan pencegahan kesehatan. Pencegahan dengan menjaga kesehatan seperti menjaga jarak minimal 2 meter satu sama lain, memakai masker, rajin untuk mencuci tangan, dan penyemprotan disinfektan setiap rumah, yang kemudian disusul dengan kebijakan Pembatasan Sosial Berskala Besar (PSBB). Kebijakan pembatasan sosial (social distancing) ini mengakibatkan seluruh masyarakat dihimbau untuk tetap dirumah. Himbauan stay at home berdampak pada banyak sektor khususnya sektor perbankan sehingga berimbas terhadap perlambatan pertumbuhan pembiayaan, meningkatnya pembiayaan bermasalah akibat dari banyaknya masyarakat kehilangan pekerjaan. Tentu, pembiayaan tidak lancar ini akan berdampak pada kinerja keuangan perbankan (non performing financing/NPF) (Fauzi, 2018). Pada saat masa pandemi Covid-19 Bank BNI Syariah dan Bank Syariah Mandiri menerapkan kebijakan penundaan pembayaran pembiayaan yang diperuntukkan bagi beberapa nasabah yang mengalami penurunan pendapatan atas usahanya. Kebijakan tersebut tentu dapat berdampak pada kinerja keuangan perbankan syariah.

Merujuk pada permasalahan di atas, peneliti bermaksud menjadikan topik tersebut ke dalam sebuah studi mengenai kinerja keuangan sektor perbankan syariah sebagai dampak dari Covid-19. Penelitian ini mempunyai tujuan yakni guna melakukan analisis perbandingan

\footnotetext{
${ }^{6}$ Monica Olivia. "Analisis Komparasi Kinerja Keuangan Bank Syariah dan Bank Konvensional dengan Pendekatan Camel Pada PT BNI Syariah Tbk dan Bank BNI Tbk Periode 2014-2018". Jurnal Audit dan Akuntansi, Vol.3, No.1 (2019): 73-88.

${ }^{7}$ www.covid19.go.id, diakses pada 21 April 2020.
} 
kinerja keuangan diantara Bank Syariah Mandiri dengan Bank BNI Syariah selama pandemi Covid-19.

\section{METODE PENELITIAN}

Penelitian ini akan mempergunakan teknik pengumpulan data dokumentasi serta studi pustaka. Dokumentasi merupakan proses dalam pengumpulan data melalui arsip maupun dokumen dan juga catatan laporan keuangan triwulan 1, 2, 3 dan 4 untuk tahun 2019 dan triwulan 1 untuk tahun 2020 dari dua perbankan syariah yakni Bank Syariah Mandiri dan Bank BNI Syariah. Penelitian ini juga akan mempergunakan jenis penelitian yakni penelitian komparatif. Penelitian komparatif adalah sebuah penelitian yang melakukan perbandingan kinerja keuangan diantara Bank Syariah Mandiri dengan Bank BNI Syariah. Uji komparatif dilakukan dengan pengujian melalui Independen Sampel T-test. Pengujian Independen Sampel T-test memiliki prinsip kerja yang nantinya memperbandingkan mean diantara dua macam sampel penelitian diantara dua sampel yang memiliki hubungan. Tujuan digunakannya Independen Sampel T-test adalah untuk menguji dua sampel penelitian, memiliki persamaan mean ataupun tidak memiliki persamaan, agar nantinya bisa dihasilkan ataupun ditemukan adanya perbandingan diantara dua sampel.

\section{HASIL DAN PEMBAHASAN}

\section{Deskripsi Variabel Rasio Keuangan}

Berdasarkan tingkatan rasio bisa didapatkan hasil mengenai penilaian kinerja yang dipergunakan pada sebuah perbankan maupun perusahaan. Pada tabel 7 di bawah ini merupakan tingkat rasio Bank BNI Syariah dan Bank Syariah Mandiri. Kinerja keuangan bank bisa diketahui melalui tingkatan rasio berikut:

Tabel 7

Rasio KeuanganBank BNI Syariah

Dan Bank Syariah Mandiri

\begin{tabular}{cccccccc}
\hline NAMA & TAHUN & TRIWULAN & CAR\% & ROA\% & ROE\% & NPF\% & BOPO\% \\
\hline & & 1 & 18,23 & 1,66 & 12,65 & 2,90 & 82,96 \\
Bank BNI & 2019 & 2 & 18,38 & 1,97 & 14,62 & 3,03 & 79,85 \\
Syariah & & 3 & 18,73 & 1,91 & 14,09 & 3,05 & 80,67 \\
& \multirow{2}{*}{2020} & 4 & 18,88 & 1,82 & 13,54 & 3,33 & 81,26 \\
& & 1 & 12,29 & 2,24 & 17,95 & 3,80 & 76,53 \\
Bank Syariah & 2019 & 2 & 15.62 & 1.33 & 12.59 & 3.06 & 86.03 \\
Mandiri & & 3 & 15.84 & 1.50 & 14.01 & 2.89 & 83.91 \\
& & 4 & 16.08 & 1.57 & 14.55 & 2.66 & 83.28 \\
& 2020 & 1 & 16.43 & 1.69 & 15.65 & 2.44 & 82.89 \\
& & 1 & 1.74 & 16.39 & 2.49 & 82.87 \\
\hline
\end{tabular}

Sumber: Data Perbankan Syariah Diolah, 2020

Pada tabel 7 di atas, Bank BNI Syariah pada tahun 2019 triwulan 1 memperlihatkan bahwa CAR yang dimiliki adalah sebesar $18,23 \%$ dan pada triwulan 4 mengalami kenaikan

Iqtishadia: Jurnal Ekonomi dan Perbankan Syariah

Vol.7 No.2 Desember 2020 
menjadi 18,88\% tetapi pada tahun 2020 triwulan 1 mengalami penurunan menjadi 12,29\%. Bank BNI Syariah pada tahun 2019 triwulan 1 memiliki nilai ROA sebesar 1,66\% dan triwulan 3 sebesar 1,82 dan pada tahun 2020 triwulan 1 mengalami kenaikan kembali menjadi 2,24. Jika nilai ROA semakin meningkat atau semakin tinggi ROA maka bertambag baik pula kualitas Bank tersebut (Meryho, 2017). Dapat dilihat dari nilai ROA Bank BNI Syariah memiliki kualitas bank yang lebih baik dibandingkan dengan Bank Syariah Mandiri. Bank BNI Syariah pada tahun 2019 triwulan 1 memiliki ROE sebesar 12,65\% dan pada triwulan 4 mengalami penurunan menjadi $13,54 \%$ disbanding triwulan 2 , tetapi pada tahun 2020 triwulan 1 mengalami kenaikan sebesar 17,95\%. Jika nilai ROE semakin menurun atau rendah maka kualitas Bank pun akan menurun, tetapi jika nilai ROE semakin tinggi atau meningkat maka semakin baik pula kualitas Bank tersebut (Meryho, 2017). Dapat dilihat dari nilai ROE Bank Syariah Mandiri memilik kualitas yang lebih baik dibandingkan dengan Bank BNI Syariah. Bank BNI Syariah pada tahun 2019 triwulan 1 memiliki NPF sebesar 2,90\% dan pada triwulan 4 mengalami kenaikan menjadi 3,33\% dan pada tahun 2020 triwulan 4 mengalami kenaikan kembali menjadi 3,80\%. Rasio NPF sebagai alat untuk mengukur seberapa besar tingkat kualitas aktiva tersebut produktif yang berhubungan dengan pinjaman bermasalah, jadi hal tersebut dapat dikatakan bahwa semakin rendah rasio NPF menunjukan kualitas aktiva produk tersebut baik. Jika dilihat dari nilai NPF Bank Syariah Mandiri, memiliki nilai NPF lebih lebih baik, karena semakin rendah nilai NPF maka akan semakin baik kualitas aktiva suatu bank. Bank BNI Syariah pada tahun 2019 triwulan 1 memiliki BOPO sebesar 82,96\% dan pada triwulan 4 mengalami penurunan menjadi $81,26 \%$ dan untuk tahun 2020 triwulan 1 mengalami penurunan kembali menjadi 76,53.

Kinerja di atas dalam perbankan merupakan salah satu alat ukur dimana bisa memberitahukan atau memperlihatkan tentang efesien juga efektifnya suatu perbankan dalam rangka mencapai tujuan. Kinerja keuangan merupakan output dari aktivitas perusahaan yang hasil akhirnya dibuat dalam bermacam-macam bentuk angka keuangan. Penilaian kinerja bertujuan untuk menilai tingkat keberhasilan suatu bank, penilaian baik dan tidaknya suatu kinerja bank tersebut mendapatkan pengaruh dari berbagai faktor yang salah satunya yakni baik atau tidaknya juga keputusan yang akan diambil oleh manajemen. ${ }^{8}$

Banyak berbagai pihak yang berkepentingan sangat membutuhkan informasi kinerja perbankan dimana salah satunya adalah manajemen, investor, kreditur, dll. Informasi kinerja perbankan diperlukan oleh manajemen dimana informasi tersebut digunakan sebagai pengambilan sebuah keputusan investor mempergunakan berbagai informasi ini digunakan untuk keinginannya pada keputusan investasi ke dalam suatu perusahaan maupun pada perusahaan yang lainnya, dan informasi ini pun digunakan oleh kreditur guna mengambil langkah dalam menentukan kondisi keuangan untuk layak investasi atau tidak.

Hasil akhir dari informasi penilaian kinerja suatu perusahaan itu sendiri diperoleh dengan cara melaksanakan analisis pada laporan keuangan. Hasil dari informasi penilaian kinerja keuangan tersebut dipergunakan untuk pedoman guna memprediksi atau melihat keadaan keuangan pada waktu ke depan dan juga kinerja pada waktu ke depan, dan berbagai

8 Alfredo dkk. "Pengaruh Kinerja Keuangan Terhadap Nilai Perusahaan Pada perusahaan Manufaktur Di Bursa Efek Indonesia". Jurnal Manajemen, Strategi Bisnis, dan Kewirausahaan, Vol.6, No.2, (Agustus 2016), 130-138. 
hal berkaitan secara tepat dengan pengguna jasa perbankan meliputi upah, pembayaran deviden, serta kesanggupan perusahaan dalam pemenuhan komitmen pada saat jatuh tempo.

Terdapat empat rasio keuangan yang dipergunakan untuk melakukan pengukuran kinerja keuangan perusahaan seperti di bawah ini:

Capital Adequacy Ratio (CAR)

Modal adalah salah satu faktor dimana sangat vital untuk bank dalam mengembangkan usahanya, di sisi lain memiliki fungsi menjadi sumber utama keuangan aktivitas perusahaan modal, selain itu memiliki fungsi dalam menyangga berbagai hal yang bisa mendatangkan kerugian dimasa mendatang. ${ }^{9}$ Pada dasarnya modal yang dipunyai oleh perusahaan atau bank harus mencukupi dalam menghadapi semua risiko aktivitas usahanya seperti terjadinya kerugian pada bank ataupun perusahaan. Rasio kecukupan modal rasio bertujuan melihat kepastian terhadap bank untuk bisa memaksimalkan operasionalnya, sehingga tidak mengalami kerugian pada masa mendatang. Apabila modal di dalam perbankan atau perusahaan yang dimiliki itu dapat mencukupi kegiatan aktivitas perbankan maka dapat memperlancar kegiatan aktivitas yang dijalankan. ${ }^{10}$

CAR merupakan rasio yang menunjukan sudah sampai mana semua aktiva dari bank memiliki risiko seperti penyertaan, tagihan pada bank lainnya, kredit serta surat berharga, juga turut diberikan pembiayan yang berasal pada dana modal sendiri, selain mendapatkan berbagai dana yang bersumber dari luar bank. ${ }^{11}$ Rasio permodalan dirumuskan yaitu: ${ }^{12}$

$$
\text { CAR }=\frac{\text { Modal }}{\text { ATMR }} \times 100 \%
$$

\section{Tabel 2}

Kriteria Penilaian Capital Adequeency Ratio(CAR)

\begin{tabular}{|c|c|}
\hline Nilai Kredit & Keterangan \\
\hline$>8 \%$ & Sehat \\
\hline$\geq 6,5 \%-\leq 7,99 \%$ & Cukup Sehat \\
\hline$\geq 5,0 \%-\leq 6,49 \%$ & Kurang Sehat \\
\hline$\leq 4,99 \%$ & Tidak Sehat \\
\hline
\end{tabular}

\section{Rasio Rentabilitas (ROA)}

Return on Asset (ROA) adalah salah satu bentuk dari rasio profitabilitas, dengan cara mempergunakan sesudah berbagai biaya modal serta total aset yang dipunyai oleh perbankan maka dapat melihat kemampuan suatu perusahaan agar bisa mendapatkan laba/keuntungan. Dikarenakan, return on asset merupakan alat pengukuran yang dipergunakan dalam kesanggupan perusahaan serta menilai efektifitas untuk mendapatkan laba maupun keuntungan. Return On Asset (ROA) adalah rasio diantara keuntungan sebelum

9 Dahlan Siamat, Manajemen Lembaga Keuangan. (Jakarta: Lembaga Penerbit fakultas Ekonomi Universitas Indonesia, 2001), 92.

10 Dahlan Siamat, Manajemen Lembaga Kenangan. JJakarta: Lembaga Penerbit fakultas Ekonomi Universitas Indonesia, 2001), 93.

${ }^{11}$ Lukman Dendawijaya, Manajemen Perbankan. (Jakarta: Ghalia Indonesia, 2011), 121.

12 Kasmir, Analisis Laporan Keuangan. (Jakarta: Rajawali Pers, 2010), 129.

Iqtishadia: Jurnal Ekonomi dan Perbankan Syariah

Vol.7 No.2 Desember 2020 
pajak terhadap total aset suatu bank. Return on Asset (ROA) merupakan rasio keuntungan bersih sesudah pajak dimana bisa diberikan juga pengertian sebagai alat ukur untuk dapat memberikan penilaian mengenai tingkatan besaran pengembalian aktiva yang dipunyai suatu perusahaan maupun perbankan. Jika Return On Asses (ROA) bernilai positif maka dapat memperlihatkan jika dari total asset yang digunakan tersebut dalam operasional memiliki kemampuan guna menghasilkan keuntungan untuk perusahaan. Apabila Return On Asses (ROA) bernilai negatif maka dapat memperlihatkan jika dari total asset yang digunakan untuk operasional perusahaan tidak memberikan keuntungan (rugi). ${ }^{13}$ Pengukuran efektifitas rasio profitabilitas pada perusahaan dalam mendapatkan laba/keuntungan melalui pemanfaatan kepemilikan total asetnya. Rumus dalam mendapatkan ROA berdasarkan SE BI 13/30/DPNP/16 Desember 2011 yakni:

$$
\text { ROA }=\frac{\text { Laba Sebelum Pajak }}{\text { Total Aktiva }} \times 100 \%
$$

Tabel 3

Kriteria Penilaian Return On Asset (ROA)

\begin{tabular}{|c|c|}
\hline Nilai Kredit & Keterangan \\
\hline$>1,22 \%$ & Sehat \\
\hline$>0,98 \%-\leq 1,22 \%$ & Cukup Sehat \\
\hline$>0,76 \%-\leq 0,98 \%$ & Kurang Sehat \\
\hline$\leq 0,76 \%$ & Tidak Sehat \\
\hline
\end{tabular}

\section{Return on Equity (ROE)}

Return on Equity merupakan salah satu rasio profitabilias dimana adanya perbandingan diantara aset bersih meliputi ekuitas/modal dengan keuntungan bersih (net profit), dimana Rasio ROE tersebut digunakan untuk menilai besaran perolehan keuntungan/laba dari suatu perusahaan maupun perbankan melalui penyetoran modal dari pemegang saham yang dibandingkan. Rasio ROE mempergunakan korelasi diantara keuangan sesudah pajak dan modal sendiri yangmana dipergunakan suatu perusahaan maupun perbankan itu sendiri, menggunakan hubungan antara laba setelah pajak dan dengan modal sendiri yang digunakan oleh perbankan atau perusahaan, dimana modal sendiri tersebut yaitu seperi agio saham, saham prefen, laba ditahan, saham biasa ataupun berbagai cadangan lainnya.

$R O E$ dapat dikatakan sebagai harapan investor pada seluruh pendanaan yang sudah diinvestasikan maupun diberikan untuk berbagai perusahaan. Dimana Investor beranggapan jika nilai profitabilitas yang terus bertambah dalam perusahaan, lalu investor merasa memiliki ketertarikan untuk berinvestasi dan melakukan pencarian pada saham ini dikarenakan mereka mengharapkan jika pada waktu mendatang akan memperoleh pengembalia dana secara bertambah atau keuntungan. Jika permintaan saham meningkat dan dapat dikatakan naik atau meningkat maka kenaikan harga penawaran saham dapat

${ }^{13}$ Nuzul Ikhwal. "Analisis ROA dan ROE Terhadap Profitabilitas Bank Di Bursa Efek Indonesia”. Jurnal Lembaga Keuangan dan Perbankan, Vol.1, No.2, (Juli-Desember 2016), 212-227.

178

Iqtishadia: Jurnal Ekonomi dan Perbankan Syariah Vol.7 No.2 Desember 2020 
dilakukan. Jika rasio ROE tinggi dan dapat dikatakan sehat atau ideal, apabila pada ambang diantara 5-12,5\% nilai ROEnya.

Return on equity dapat dikatakan sebagai laba bersih terhadap ekuitas biasa dimana melakukan pengukuran pada tingkatan investasi pemegang saham biasa yang dikembalikan ataupun ekuitas biasa yang dikembalikan. ${ }^{14}$ Rumus ROE berdasarkan SE BI 13/30/DPNP/16 Desember 2011 yakni:

$$
\text { ROE }=\frac{\text { Laba Setelah Pajak }}{\text { Total Equitas }} \times 100 \%
$$

\section{Tabel 4}

Kriteria Penilaian Return On Equity (ROE)

\begin{tabular}{|c|c|}
\hline Nilai Kredit & Keterangan \\
\hline$>12,5 \%$ & Sehat \\
\hline $10,36 \%-\leq 12,60 \%$ & Cukup Sehat \\
\hline $12,61 \%-\leq 14,85 \%$ & Kurang Sehat \\
\hline$>14,85 \%$ & Tidak Sehat \\
\hline
\end{tabular}

Not Performing Financing (NPF)

Not Performing Financing (NPF) merupakan rasio dimana bisa memberikan penggambaran suatu bank mampu atau tidaknya untuk melakukan pengelolaan pada pembiayaan bermasalah atas penyaluran pembiayaan yang dilakukan. Non Performing Financing (NPF) adalah rasio keuangan yang memperlihatkan risiko pembiayaan dimana didapatkan oleh bank yang disebabkan dari diberikannya investasi/pembiayaan dana bank dalam perbedaan portofolio. Bisa dikatakan bahwa jika semakin rendah NPF maka semakin rendah risiko pembiayaan yang ditanggung pihak perbankan. Begitupun jika bank tersebut memiliki NPF tinggi, maka memperlihatkan bank tidak bisa bersikap profesional dalam pengelolaan dana. ${ }^{15}$ Untuk mendapatkan nilai NPF, bisa digunakan rumus yakni:

$$
N P F=\frac{\text { pembiayaan bermasalah }}{\text { Total Pembiayaan }} \times 100 \%
$$

Tabel 5

Kriteria Penilaian Non Performing Financing (NPF)

\begin{tabular}{|c|c|}
\hline Nilai Kredit & Keterangan \\
\hline $0,00 \%-\leq 10,35 \%$ & Sehat \\
\hline $10,36 \%-\leq 12,60 \%$ & Cukup Sehat \\
\hline $12,61 \%-\leq 14,85 \%$ & Kurang Sehat \\
\hline$>14,85 \%$ & Tidak Sehat \\
\hline
\end{tabular}

${ }^{14}$ Kasmir, Analisis Laporan Keuangan. (Jakarta: Rajawali Pers, 2010), 201.

15 Yulya Aryani dkk. "Faktor-Faktor yang Mempengaruhi Non Performing Financing Pada Bank Umum Syariah Indonesia Periode 2010-2014”'. Jurnal Al Mua'₹arah, Vol. 4, No.1, (2016), 44-60.

Iqtishadia: Jurnal Ekonomi dan Perbankan Syariah

Vol.7 No.2 Desember 2020 
Rasio Efesiensi Biaya Operasional terhadap Pendapatan Operasional (BOPO)

Rasio efesiensi yaitu rasio yang dipergunakan untuk mengetahui tingkat kesanggupan suatu bank dalam melaksanakan aktivitas perusahaannya secara efisien. Rasio efesiensi digunakan istilah BOPO, untuk melakukan pengukuran tingkat kesanggupan dalam hal pengelolaan untuk dapat melakukan pengendalian terhadap dana operasional perbankan. Saat dana operasional meningkat, maka biaya yang dikeluarkan memberi dampak adanya kekurangan keuntungan sebelum pajak serta diakhir bisa terjadi penurunan keuntungan bank tersebut. ${ }^{16}$ Untuk mendapatkan nilai BOPO, bisa digunakan rumusa yakni :

$$
R O E=\frac{\text { Total Beban Operasional }}{\text { Total Pendapatan Operasional }} \times 100 \%
$$

Tabel 6

Kriteria Penilaian BOPO

\begin{tabular}{|c|c|}
\hline Nilai Kredit & Keterangan \\
\hline$<93,52 \%$ & Sehat \\
\hline $93,52 \%-94,73 \%$ & Cukup Sehat \\
\hline $94,73 \%-95,92 \%$ & Kurang Sehat \\
\hline$>95,92 \%$ & Tidak Sehat \\
\hline
\end{tabular}

\section{Uji Beda Independent Sampel T-Tes}

Uji beda independent sampel t-tes penelitian yaitu menyampaikan informasi tentang karakteristik variabel-variabel penelitian yang terdiri dari atas jumlah pengamatan atau sampel, nilai rata-rata dan standar deviasi. Pada tabel 8 di bawah ini memperlihatkan hasil uji beda independent sampel t-test untuk Bank BNI Syariah dan Bank Syariah Mandiri.

Tabel 8

Uji Beda Independent Sampel T-test

\begin{tabular}{rlllrl}
\hline & \multicolumn{1}{c}{ BANK } & N & Mean & Std. Deviation & $\begin{array}{c}\text { Std. Error } \\
\text { Mean }\end{array}$ \\
\hline CAR & BNI SYARIAH & 5 & 17.3020 & 2.81392 & 1.25843 \\
& MANDIRI & 5 & 16.0240 & .30859 & .13801 \\
\multirow{2}{*}{ ROA } & SYARIAH & & & & \\
& BNI SYARIAH & 5 & 1.9200 & .21366 & .09555 \\
& MANDIRI & 5 & 1.5660 & .16257 & .07270 \\
& SYARIAH & & & & \\
ROE & BNI SYARIAH & 5 & 14.5700 & 2.02513 & .90567 \\
& MANDIRI & 5 & 14.6380 & 1.47395 & .65917 \\
& SYARIAH & & & & \\
& & & & &
\end{tabular}

16 Dendawijaya, Lukman, Manajemen Perbankan. (Jakarta: Ghalia Indonesia, 2009), 120.

180

Iqtishadia: Jurnal Ekonomi dan Perbankan Syariah Vol.7 No.2 Desember 2020 
Analisis Perbandingan Kinerja Keuangan Bank BNI Syariah dan Bank Syariah Mandiri di masa Pandemi Covid 19

\begin{tabular}{llllrr} 
NPF & BNI SYARIAH & 5 & 3.2220 & .35912 & .16061 \\
& MANDIRI & 5 & 2.7080 & .26395 & .11804 \\
\multirow{2}{*}{ BOPO } & SYARIAH & & & & \\
& BNI SYARIAH & 5 & 80.2540 & 2.37376 & 1.06158 \\
& MANDIRI & 5 & 83.7960 & 1.31798 & .58942 \\
& SYARIAH & & & & \\
\hline
\end{tabular}

Sumber: Data Perbankan Syariah Diolah 2020

CAR untuk Bank BNI Syariah memiliki nilai mean sebesar 17.3020 dan nilai standar deviasinya sebesar 2.81392 dan untuk CAR Bank Syariah Mandiri memiliki nilai mean sebesar 16.0240 dan nilai standar deviasi sebesar 0.30859. ROA untuk Bank BNI Syariah memiliki nilai mean sebesar 1.9200 dan nilai standar deviasinya sebesar 0.21366 dan untuk CAR Bank Syariah Mandiri memiliki nilai mean sebesar 1.5660 dan nilai standar deviasi sebesar 0.16257.ROE untuk Bank BNI Syariah memiliki nilai mean sebesar 14.5700 dan nilai standar deviasinya sebesar 2.02513 dan untuk ROE Bank Syariah Mandiri memiliki nilai mean sebesar 14.6380 dan nilai standar deviasinya sebesar 1.47395. NPF untuk Bank BNI Syariah memiliki nilai mean sebesar 3.2220 dan nilai standar deviasinya sebesar 0.35912 dan untuk NPF Bank Syariah Mandiri memiliki nilai mean sebesar 2.7080 dan nilai standar deviasinya sebesar 0.26395. BOPO untuk Bank BNI Syariah memiliki nilai mean sebesar 80.2540 dan nilai standar deviasi sebesar 2.37376 dan untuk BOPO Bank Syariah Mandiri memiliki nilai mean sebesar 80.2540 dan nilai standar deviasi sebesar 2.37376 dan untuk BOPO Bank Syariah Mandiri memiliki nilai mean sebesar 83.7960 dan nilai standar deviasinya sebesar 1.31798 .

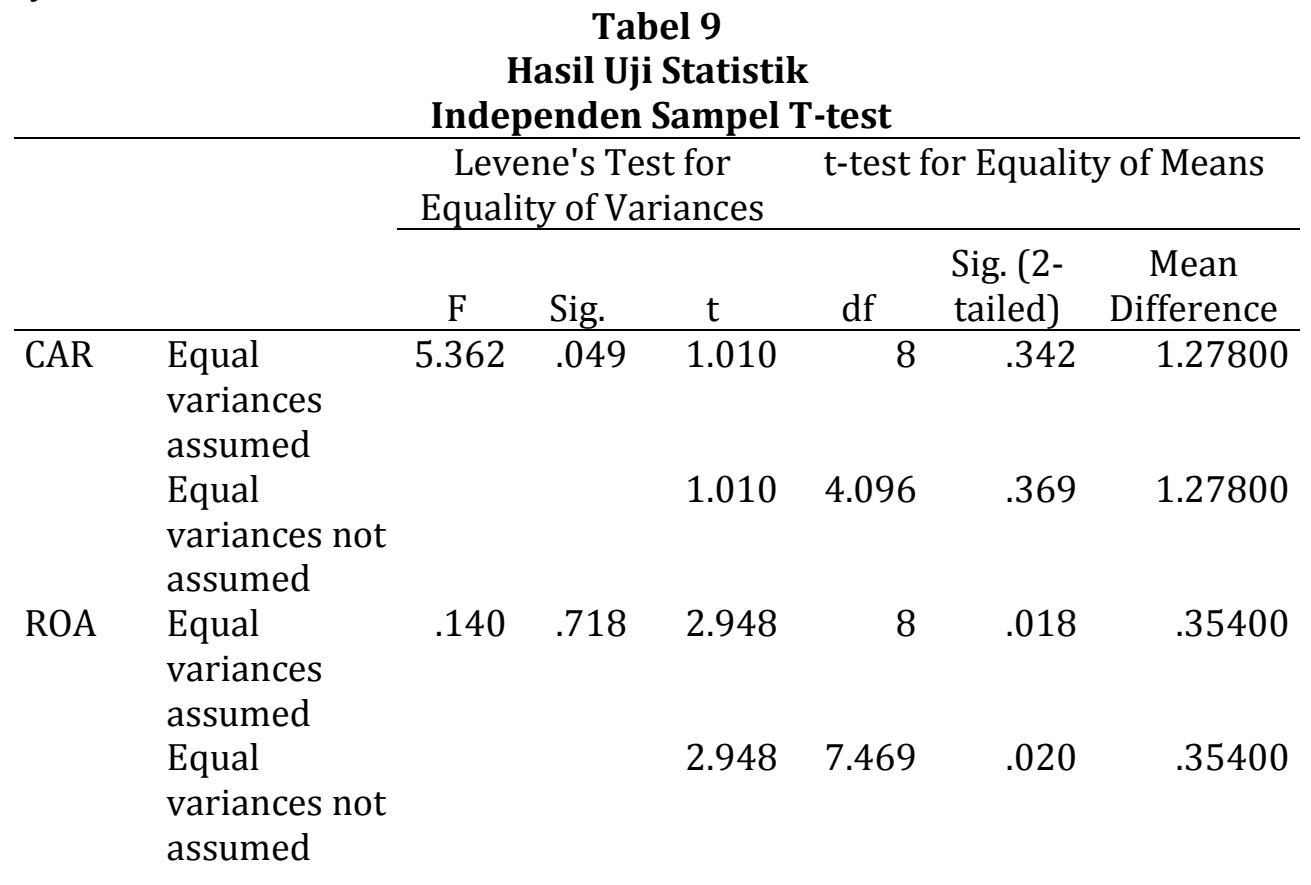

Iqtishadia: Jurnal Ekonomi dan Perbankan Syariah

Vol.7 No.2 Desember 2020 
Yoga Adi Surya dan Binti Nur Asiyah

\begin{tabular}{|c|c|c|c|c|c|c|c|}
\hline \multirow[t]{2}{*}{ ROE } & $\begin{array}{l}\text { Equal } \\
\text { variances } \\
\text { assumed }\end{array}$ & .148 & .710 & -.061 & 8 & .953 & -.06800 \\
\hline & $\begin{array}{l}\text { Equal } \\
\text { variances not } \\
\text { assumed }\end{array}$ & & & -.061 & 7.309 & .953 & -.06800 \\
\hline \multirow[t]{2}{*}{ NPF } & $\begin{array}{l}\text { Equal } \\
\text { variances } \\
\text { assumed }\end{array}$ & .389 & .550 & 2.579 & 8 & .033 & .51400 \\
\hline & $\begin{array}{l}\text { Equal } \\
\text { variances not } \\
\text { assumed }\end{array}$ & & & 2.579 & 7.345 & .035 & .51400 \\
\hline \multirow[t]{2}{*}{ BOPO } & $\begin{array}{l}\text { Equal } \\
\text { variances } \\
\text { assumed }\end{array}$ & .886 & .374 & -2.917 & 8 & .019 & -3.54200 \\
\hline & $\begin{array}{l}\text { Equal } \\
\text { variances not } \\
\text { assumed }\end{array}$ & & & -2.917 & 6.252 & .025 & -3.54200 \\
\hline
\end{tabular}

Sumber: Data Perbankan Syariah Diolah 2020

Dari tabel 9 di atas menunjukkan jika nilai signifikansi CAR yaitu sebesar 0.342 , nilai tersebut lebih besar dari 0,342 >0,005. Hal tersebut membuktikan bahwa kinerja bank BNI Syariah dengan Bank Syariah Mandiri tidak adanya perbedaan yang signifikan. Dari tabel 9 di atas terlihat bahwa nilai signifikansi ROA sebesar 0.018, nilai tersebut lebih kecil dari 0,018< 0.005. hal tersebut membuktikan bahwa kinerja keuangan Bank BNI Syariah dengan Bank Syariah Mandiri adanya perbedaan yang signifikan. Dari tabel 9 di atas terlihat bahwa nilai signifikansi ROE sebesar 0.953, nilai tersebut lebih besar dari 0,953 >0,005. Hal tersebut membuktikan bahwa kinerja keuangan Bank BNI Syariah dengan Bank Syariah Mandiri tidak adanya perbedaan yang signifikan. Dari tabel 9 di atas terlihat bahwa nilai signifikansi NPF sebesar 0,033, nilai tersebut lebih kecil dari 0,033 <0,005. Hal tersebut membuktikan bahwa kinerja keuangan bank BNI Syariah dengan Bank Syariah Mandiri adanya perbedaan yang signifikan. Dari tabel 9 di atas menunjukkan bahwa nilai signifikansi BOPO sebesar 0,019, nilai tersebut lebih kecil dari 0,019<0,005. Hal tersebut membuktikan bahwa kinerja keuangan Bank BNI Syariah dengan Bank Syariah Mandiri adanya perbedaan yang signifikan.

\section{PEMBAHASAN}

\section{Perbandingan Kinerja Keuangan Bank BNI Syariah dengan Bank Syariah Mandiri berdasarkan Rasio Pemodalan (CAR)}

Berdasarkan hasil analisis dari nilai rasio permodalan (CAR) dan pada nilai rata-rata untuk tahun 2019-2020 pada Bank BNI Syariah dan Bank Syariah Mandiri yang kemudian dilakukan perbandingan, menunjukkan bahwa rasio CAR yang dimiliki oleh Bank BNI Syariah rata-rata 17,3020. Hal ini lebih tinggi dibandingkan dengan CAR Bank Syariah Mandiri dengan rata-rata 16,0240 apalagi untuk dimasa pandemi Covid-19 tersebut, karena teori 
menyatakan bahwa jika semakin tinggi atau besar nilai rasio CAR maka hal tersebut memperlihatkan kemampuan bank yang semakin baik dalam menghadapi kemungkinan terjadinya risiko kerugian. ${ }^{17}$ Maka dapat dikatakan jika Bank BNI Syariah memiliki kinerja yang lebih baik dibandingkan dengan Bank Syariah Mandiri. Walaupun rasio CAR keduanya dapat dikatakan sehat atau ideal dimana, terdapat ketetapan atau ketentuan pada Bank Indonesia (BI) bahwa tentang kewajiban penyedian modal minimum, bahwa standar CAR yang ditentukan idealnya atau yang terbaik adalah sebesar lebih dari $8 \%$ dan hal tersebut dapat dikatakan sehat.

Berdasarkan hasil pengujian dengan menggunakan independen sampel t-test terhadap variabel CAR Hasil pengujian menunjukkan jika equal variances assumed dengan $\mathrm{F}$ hitung (diperkirakan bahwa kedua varian sama) yakni sebesar 5.362 dengan nilai signifikasi sebesar 0,342 ( $\mathrm{P}>0.05$ ), jadi bisa dinyatakan jika kedua varian tersebut secara signifikan tidak terdapat perbedaan yaitu antara Bank Syariah Mandiri dengan Bank BNI Syariah.

Hasil penelitian ini didukung atau konsisten dengan penelitian yang dilakukan oleh Dian Fitriah dan Kurniasih yang meneliti tentang analisis perbandingan keuangan perbankan syariah yang memiliki hasil bahwa kinerja keuangan Bank BNI lebih baik dari pada BRI Syariah, tetapi berbeda di dalam penelitiannya secara signifikan adanya perbedaan yang signifikan. ${ }^{18}$

\section{Perbandingan Kinerja Keuangan Bank BNI Syariah dengan Bank Syariah Mandiri berdasarkan Rasio Rentabilitas (ROA)}

Berdasarkan hasil analisis dari nilai rasio rentabilitas (ROA) dan pada nilai rata-rata untuk tahun 2019-2020 pada Bank BNI Syariah dan Bank Syariah Mandiri yang kemudian dilakukan perbandingan, menunjukkan bahwa rasio ROA yang dimiliki oleh Bank BNI Syariah (rata-rata sebesar 1,92) lebih tinggi dibandingkan dengan ROA Bank Syariah Mandiri $(1,566)$ apalagi untuk dimasa pandemi Covid-19 tersebut, karena teori menyatakan bahwa semakin besar atau tinggi nilai rasio ROA maka mengindikasikan bahwa semakin bank tersebut dalam mengelola atau menggunakan asset yang dimiliki guna untuk mendapatkan keuntungan. ${ }^{19}$ Maka dapat dikatakan jika Bank BNI Syariah memiliki kinerja yang lebih baik dibandingkan dengan Bank Syariah Mandiri. Walaupun rasio ROA keduanya dapat dikatakan sehat atau ideal dimana, terdapat ketetapan atau ketentuan pada Bank Indonesia (BI) bahwa tentang kewajiban penyedian modal minimum, bahwa standar ROA yang ditentukan idealnya atau yang terbaik adalah sebesar lebih dari 1,22\% dan hal tersebut dapat dikatakan sehat.

Berdasarkan hasil pengujian menggunakan independen sampel $t$-test terhadap variabel ROA Hasil pengujian memperlihatkan jika nilai equal variances assumed dengan $\mathrm{F}$ hitung (diperkirakan bahwa kedua varian sama) yakni sebesar 0,140 dengan nilai signifikansi

17 Duwi Hardianti dan Muhammad Saifi. "Analisis Perbandingan Kinerja Keuangan Bank Umum Konvensional Dan Bank Umum Syarian Berdasarkan Rasio Keuangan Bank". Jurnal Administrasi Bisnis (JAB), Vol. 60, No. 2, (Juli 2018), 10-18.

${ }_{18}$ Dian Asri Fitriah dan Afiati Kurniansyah. "Analisis Perbandingan Kinerja Keuangan Perbankan Syariah (Studi BRI Syariah dan BNI Syariah)”. Jurnal Nisbah, Vol. 2, No. 2, (2016), 256-264.

${ }_{19}$ Duwi Hardianti dan Muhammad Saifi. "Analisis Perbandingan Kinerja Keuangan Bank Umum Konvensional Dan Bank Umum Syarian Berdasarkan Rasio Keuangan Bank". Jurnal Administrasi Bisnis (JAB), Vol. 60, No. 2, (Juli 2018), 10-18.

Iqtishadia: Jurnal Ekonomi dan Perbankan Syariah

Vol.7 No.2 Desember 2020 
sebesar 0,018 $(\mathrm{P}<0.05)$, jadi bisa dinyatakan jika kedua varian tersebut secara signifikan terdapat perbedaan yaitu antara Bank Syariah Mandiri dengan Bank BNI Syariah.

Hasil penelitian ini didukung atau konsisten dengan penelitian yang dilakukan oleh Munadi dkk (2017) yang melakukan analisis perbandingan kinerja keuangan pada Bank Rakyat Indonesia dan Bank Mandiri menyatakan bahwa adanya perbedaan secara signifikan.20

\section{Perbandingan Kinerja Keuangan Bank BNI Syariah dengan Bank Syariah Mandiri berdasarkan Return On Equity (ROE)}

Berdasarkan hasil pengujian dan di analisis dari nilai rasio ROE dan pada nilai rata-rata untuk tahun 2019-2020 pada Bank BNI Syariah dan Bank Syariah Mandiri yang kemudian dilakukan perbandingan, menunjukkan bahwa rasio ROE yang dimiliki oleh Bank Syariah Mandiri (rata-rata 14,638) lebih tinggi dibandingkan dengan ROE Bank BNI Syariah $(14,57)$ apalagi untuk dimasa pandemi Covid-19 tersebut, karena menurut teori bahwa semakin tinggi nilai rasio ROE maka semakin bank tersebut dalam menghasilkan laba atas ekuitas yang dimiliki dimana hal tersebut juga akan mengingkatkan nilai perusahaan. ${ }^{21}$ Maka dapat dikatakan jika Bank Syariah Mandiri memiliki kinerja yang lebih baik dibandingkan dengan Bank BNI Syariah. Walaupun rasio ROE keduanya dapat dikatakan sehat atau ideal dimana, terdapat ketetapan atau ketentuan pada Bank Indonesia (BI) bahwa tentang kewajiban penyedian modal minimum, bahwa standar ROE yang ditentukan idealnya atau yang terbaik adalah sebesar lebih dari $12 \%$ dan hal tersebut dapat dikatakan sehat.

Berdasarkan hasil pengujian menggunakan independen sampel t-test terhadap variabel ROE Hasil pengujian meperlihatkan jika equal variances assumed dengan $\mathrm{F}$ hitung (diperkirakan bahwa kedua varian sama) yakni sebesar 0,148 dengan nilai signifikansi sebesar 0,019 $(\mathrm{P}<0.05)$, jadi bisa dinyatakan jika kedua varian tersebut secara signifikan terdapat perbedaan yaitu antara Bank Syariah Mandiri dengan Bank BNI Syariah.

Hasil penelitian ini didukung atau konsisten dengan penelitian yang dilakukan oleh Arinta yang meneliti tentang analisis perbandingan kinerja keuangan antara bank syariah dan bank konvensional studi kasus pada Bank Syariah Mandiri dan Bank Mandiri, dan berdasarkan analisis dari peneltiannya tersebut menunjukkan jika Bank Syariah Mandiri memiliki rasio ROE yang lebih baik. ${ }^{22}$

\section{Perbandingan Kinerja Keuangan Bank BNI Syariah dengan Bank Syariah Mandiri berdasarkan Non Performing Financing (NPF)}

\footnotetext{
20 Meryho M Munadi. "Analisis Perbandingan Kinerja Keuangan Pada Bank Rakyat Indonesia (Persero) Tbk dan Bank Mandri (Persero) Tbk Peride 2012-2015”. Jurnal EMBA, Vol.5, No.2, (Juni 2017), 656-665.

${ }^{21}$ Duwi Hardianti dan Muhammad Saifi. "Analisis Perbandingan Kinerja Keuangan Bank Umum Konvensional Dan Bank Umum Syarian Berdasarkan Rasio Keuangan Bank". Jurnal Administrasi Bisnis (JAB), Vol. 60, No. 2, (Juli 2018), 10-18.

${ }^{22}$ Yusvita Nena Arinta. "Analisis Perbandingan Kinerja Keuangan Antara Bank Syariah dan Bank Konvensional (Studi Pada Bank Syariah Mandiri dan Bank Mandiri)". Vol.7, No.1, (Juni 2016), 119140.
} 
Berdasarkan hasil analisis dari nilai rasio NPF dan pada nilai rata-rata untuk tahun 2019-2020 pada Bank BNI Syariah dan Bank Syariah Mandiri yang kemudian dilakukan perbandingan, menunjukkan bahwa rasio NPF yang dimiliki oleh Bank BNI Syariah (rata-rata $3,222)$ lebih tinggi dibandingkan dengan NPF Bank Syariah Mandiri $(2,078)$, apalagi untuk dimasa pandemi Covid-19 tersebut, karena teori menyatakan bahwa jika semakin besar nilai rasio NPF maka menunjukkan bahwa semakin bank tersebut dalam kondisi yang tidak sehat akibat adanya pembiayaan bermasalah yang dapat menimbulkan laba yang akan diterima oleh bank akan menurun. Sebagaimana paper Asiyah, disebutkan bahwa kualitas aktiva kurang lancer dan macet berpengaruh negative terhadap profitabilitas. ${ }^{23}$ Maka dapat dikatakan jika Bank Syariah Mandiri memiliki kinerja yang lebih baik dalam meminimalisir risiko kredit bermasalah dari pada dengan Bank BNI Syariah. Walaupun rasio NPF keduanya dapat dikatakan sehat atau ideal dimana, terdapat ketetapan atau ketentuan pada Bank Indonesia (BI) bahwa standar NPF yang ditentukan idealnya atau yang terbaik adalah $0,00 \%$ - $\leq 10,35 \%$ dan hal tersebut dapat dikatakan sehat.

Berdasarkan hasil pengujian menggunakan independen sampel t-test terhadap variabel NPF Hasil pengujian menunjukan jika equal variances assumed dengan F hitung (diperkirakan bahwa kedua varian sama) yakni sebesar 0,389 dengan nilai signifikansi sebesar 0,033 ( $<$ 0.05 ), jadi bisa dinyatakan jika kedua varian tersebut secara signifikan terdapat perbedaan yaitu antara Bank Syariah Mandiri dengan Bank BNI Syariah.

Hasil penelitian ini didukung atau konsisten dengan penelitian yang dilakukan oleh Vivin, dan Wahono yang meneliti tentang analisis perbandingan kinerja keuangan bank umum syariah dengan bank umum konvensional di Indonesia yang menyatakan bahwa adanya perbedaan secara signifikan. ${ }^{24}$ Agar NPF dapat dikendalikan, apalagi dalam situasi pandemic covid 19, maka diperlukan mengedepankan implementasi Islamic prudential banking 25 , agar nasabah merasakan keadilan dalam bertransaksi di bank syariah.

\section{Perbandingan Kinerja Keuangan Bank BNI Syariah dengan Bank Syariah Mandiri berdasarkan Rasio Efesiensi Biaya Operasional terhadap Pendapatan Operasional (BOPO)}

Berdasarkan hasil analisis dari nilai rasio BOPO dan pada nilai rata-rata untuk tahun 2019-2020 pada Bank BNI Syariah dan Bank Syariah Mandiri yang kemudian dilakukan perbandingan, menunjukan bahwa rasio BOPO yang dimiliki oleh Bank BNI Syariah (rata-rata 80,254) lebih rendah dibandingkan dengan BOPO Bank Syariah Mandiri $(83,796)$ apalagi untuk dimasa pandemi Covid-19 tersebut, karena teori menyatakan bahwa semakin rendah

\footnotetext{
${ }^{23}$ Binti Nur Asiyah, "Pengaruh Kualitas Portofolio Pembiayaan terhadap Profitabilitas Bank Mega Syariah”, Jurnal An-Nisbah, Vol 3 No 2 April 2017

24 Yenny Anor Vivin dan Budi Wahono. "Analisis Perbandingan Kinerja Keuangan Bank Umum Syariah dan Bank Umum Konvensional Di Indonesia". E-jurnal Riset Manajemen, (2017).

${ }^{25}$ Binti Nur Asiyah, M. Ridlwan Nasir, dan Muhamad Ahsan, "Islamic Prudential Banking Concept to Reduce Non Performing Financing; Literature review", Jurnal Iqtishadia, Vol 12 No 2 April 2019, DOI : 10.21043 /iqtishadia.v12i2.5641
}

Iqtishadia: Jurnal Ekonomi dan Perbankan Syariah

Vol.7 No.2 Desember 2020 
nilai rasio BOPO maka menunjukkan bahwa semakin efisien bank dalam mengelola biaya operasionalnya. ${ }^{26}$

Maka dapat dikatakan jika Bank BNI Syariah memiliki kinerja yang lebih dari pada Bank Syariah Mandiri untuk dapat menghasilkan laba dengan cara meningkatkan pendapatan operasionalnya dan memperkecil biaya-biaya operasional yang dikeluarkan. Walaupun rasio BOPO keduanya dapat dikatakan sehat atau ideal dimana, terdapat ketetapan atau ketentuan pada Bank Indonesia (BI) bahwa tentang kewajiban penyedian modal minimum, bahwa standar BOPO yang ditentukan idealnya atau yang terbaik adalah dibawah $93.52 \%$ dan hal tersebut dapat dikatakan sehat.

Berdasarkan hasil pengujian menggunakan independen sampel t-test terhadap variabel BOPO Hasil pengujian memperlihatkan jika equal variances assumed dengan $\mathrm{F}$ hitung (diperkirakan bahwa kedua varian sama) yakni sebesar 0,886 dengan nilai probabilitas 0,019 ( $\mathrm{P}>0.05)$, jadi bisa dinyatakan jika kedua varian tersebut secara signifikan terdapat perbedaan yaitu antara Bank Syariah Mandiri dengan Bank BNI Syariah.

Hasil penelitian ini didukung atau konsisten dengan penelitian yang dilakukan oleh Vivin, dan Wahono yang meneliti tentang analisis perbandingan kinerja keuangan bank umum syariah dengan bank umum konvensional di Indonesia yang menyatakan hasil penelitiannya bahwa adanya perbedaan secara signifikan. ${ }^{27}$

\section{PENUTUP}

Merujuk pada hasil dan pembahasan di atas, oleh karena itu kesimpulan pada penelitian ini adalah berdasarkan hasil pengujian terlihat bahwa secara signifikan terdapat perbedaan diantara kinerja keuangan Bank Syariah Mandiri dan Bank BNI Syariah dari aspek ROA, NPF dan BOPO, dan sedangkan dari segi aspek CAR dan ROE menunjukkan bahwa secara signifikan tidak adanya perbedaan antara kinerja keuangan Bank Syariah Mandiri dan Bank BNI Syariah. Berdasarkan hasil dari analisis nilai rasio keuangan dan rata-rata pada nilai rasio keuangan dapat disimpulkan bahwa Bank BNI Syariah memiliki kinerja keuangan yang lebih baik dari pada Bank Syariah Mandiri yang berdasarkan rasio CAR, ROA, dan BOPO, dan untuk Bank Syariah Mandiri memiliki kinerja keuangan yang lebih baik dari pada Bank BNI Syariah berdasarkan rasio ROE dan NPF.

\section{DAFTAR PUSTAKA}

Alfredo dkk. "Pengaruh Kinerja Keuangan Terhadap Nilai Perusahaan Pada perusahaan Manufaktur Di Bursa Efek Indonesia". Jurnal Manajemen, Strategi Bisnis, dan Kewirausahaan, Vol.6, No.2, (Agustus 2016), 130-138.

Binti Nur Asiyah, "Pengaruh Kualitas Portofolio Pembiayaan terhadap Profitabilitas Bank Mega Syariah", Jurnal An-Nisbah, Vol 3 No 2 April 2017

\footnotetext{
${ }^{26}$ Duwi Hardianti dan Muhammad Saifi. "Analisis Perbandingan Kinerja Keuangan Bank Umum Konvensional Dan Bank Umum Syarian Berdasarkan Rasio Keuangan Bank". Jurnal Administrasi Bisnis (JAB), Vol. 60, No. 2, (Juli 2018), 10-18.

${ }^{27}$ Yenny Anor Vivin dan Budi Wahono. "Analisis Perbandingan Kinerja Keuangan Bank Umum Syariah dan Bank Umum Konvensional Di Indonesia”. E-jurnal Riset Manajemen, (2017).
} 
Binti Nur Asiyah, M. Ridlwan Nasir, dan Muhamad Ahsan, "Islamic Prudential Banking Concept to Reduce Non Performing Financing; Literature review", Jurnal Iqtishadia, Vol 12 No 2 April 2019, DOI : 10.21043/iqtishadia.v12i2.5641

Dahlan Siamat, Manajemen Lembaga Keuangan. (Jakarta: Lembaga Penerbit fakultas Ekonomi Universitas Indonesia, 2001).

Dendawijaya, Lukman, Manajemen Perbankan. (Jakarta: Ghalia Indonesia, 2009).

Dian Asri Fitriah dan Afiati Kurniansyah. "Analisis Perbandingan Kinerja Keuangan Perbankan Syariah (Studi BRI Syariah dan BNI Syariah)". Jurnal Nisbah, Vol. 2, No. 2, (2016), 256-264

Duwi Hardianti dan Muhammad Saifi. "Analisis Perbandingan Kinerja Keuangan Bank Umum Konvensional Dan Bank Umum Syarian Berdasarkan Rasio Keuangan Bank". Jurnal Administrasi Bisnis (JAB), Vol. 60, No. 2, (Juli 2018), 10-18

Heri Sudarsono, Bank dan Lembaga Kenangan Syariab: Deskripsi dan Ilustrasi. (Yogyakarta: Eksoria, 2012).

Kasmir, Analisis Laporan Kenangan. (Jakarta: Rajawali Pers, 2010).

Lukman Dendawijaya, Manajemen Perbankan. (Jakarta: Ghalia Indonesia, 2011).

Monica Olivia. "Analisis Komparasi Kinerja Keuangan Bank Syariah dan Bank Konvensional dengan Pendekatan Camel Pada PT BNI Syariah Tbk dan Bank BNI Tbk Periode 20142018". Jurnal Audit dan Akuntansi, Vol.3, No.1 (2019): 73-88.

Nuzul Ikhwal. "Analisis ROA dan ROE Terhadap Profitabilitas Bank Di Bursa Efek Indonesia". Jurnal Lembaga Kenangan dan Perbankan, Vol.1, No.2, (Juli-Desember 2016), 212-227.

Sutiman, "Analisis Rasio ROE dan ROA Dalam Menilai Tingkat Kesehatan Pada PT Bank Mandiri (Persero) Tbk Tahun 2012-2017”, Jurnal Mandiri: Ilmu Pengetahuan, Seni, dan Teknologi, Vol. 3, No. 1 (Juni 2019):20-36.

Sutiman, "Analisis Rasio ROE dan ROA Dalam Menilai Tingkat Kesehatan Pada PT Bank Mandiri (Persero) Tbk Tahun 2012-2017”, Jurnal Mandiri: Ilmu Pengetabuan, Seni, dan Teknologi, Vol. 3, No. 1 (Juni 2019):20-36.

Totok Budisantoso dan Nuritomo, Bank dan Lembaga Kenangan Lain. (Jakarta: Salemba Empat, 2014,).

Yenny Anor Vivin dan Budi Wahono. "Analisis Perbandingan Kinerja Keuangan Bank Umum Syariah dan Bank Umum Konvensional Di Indonesia”. E-jurnal Riset Manajemen, (2017).

Yulya Aryani dkk. "Faktor-Faktor yang Mempengaruhi Non Performing Financing Pada Bank Umum Syariah Indonesia Periode 2010-2014”. Jurnal Al Mua'zarah, Vol. 4, No.1, (2016), 44-60.

Surat Edaran Bank Indonesia No. 13/30/ DPNP 16 Desember 2012, Diakses Pada 15 Juni 2020 dari http://www.bi.go.id

Undang-Undang RI Nomor 10 Tahun 1998 tentang Perbankan

http:///bnisyariah.co.id Diakses pada 15 Juni 2020

http://covid19.go.id, diakses pada 15 Juni 2020

http://www.ojk.go.id,diakses pada 1 Juli 2020 